DIMENSI, VOL. 8, NO. 1 : 90-115

MARET 2019

ISSN: 2085-9996

\title{
POSITIVE POLITENESS STRATEGIES USED IN CONVERSATION BY HOTEL STAFF HOUSEKEEPING OF PANORAMA REGENCY HOTEL BATAM
}

\section{STRATEGI KEBIJAKAN POSITIF YANG DIGUNAKAN DALAM KONVERSASI OLEH STAFF HOUSEKEEPING HOTEL PANORAMA REGENCY HOTEL BATAM}

\author{
Supardi ${ }^{1}$, Nasruji ${ }^{2}$, Rona Miduk Lasmaria Simanullang ${ }^{2}$ \\ ${ }^{I}$ Prodi Magister Manajemen, Pascasarjana, UNRIKA, Indonesia \\ ${ }^{2}$ Prodi Pendidikan Sejarah, FKIP, UNRIKA, Indonesia \\ ${ }^{3}$ Prodi Pendidikan Bahasa Inggris, FKIP, UNRIKA, Indonesia \\ Email: sofardy@yahoo.com
}

\begin{abstract}
This study was aimed to analyze the conversation between the hotel staff with the guest. This study had objectives to identify the positive politeness strategies by using Brown and Levinson theory (1987). The data found 109 data and analyzed qualitatively based on the conversation between the staff and the guests at the Panorama Regency Hotel, Batam. The writer has carried of the data analysis. The then writer found 109 data that positive politeness consist of 106 data, they are: strategy 1, 6 data (5,40\% ), strategy 2, 3 data (2,70\% ), strategy 3, 5 data (4,50\%), strategy 4, 10 data (9,00\% ), strategy 5, 23 data (21,10\%), strategy 6, 5data(4,50 \%), strategy 7, 5 data (4,50\%), strategy 8, 3 data (2,70\%), strategy 9, 5 data (4,50\%), strategy 10, 3 data (2,70 \%), strategy 11 , 5 data (4,50\%), strategy 12, 4 data (3,60 \%), strategy 13, 7 data (6,30 \%), strategy 14, 1 data (0,90 \%), and strategy 15, 7 data (6,30 \%). This study concluded that positive politeness strategies based on the dialogue between the hotel staff and the guest who has occupied at Panorama Regency Hotel, Batam. The most frequently used is strategy 5, 23 times used (21,10\%). This strategy is aimed to safe topics are used to allow speaker to stress agreement with hearer. In this case, the speakers did it to stress his or her agreement with hearer (guests). Therefore this was to satisfy hearer's desire to be 'right' or corroborated in his opinion. Therefore, mostly hotel staff used agreement when they serve the quests. This is done to make the guests do not complain and stay at home when they stay at the hotel.
\end{abstract}

Key words: Politeness, Hotel Staff, Conversation

\begin{abstract}
Abstrak
Penelitian ini bertujuan untuk menganalisis percakapan antara staf hotel dengan tamu. Penelitian ini memiliki tujuan untuk mengidentifikasi strategi kesopanan positif dengan menggunakan teori Brown dan Levinson (1987). Data tersebut menemukan 109 data dan dianalisis secara kualitatif berdasarkan percakapan antara staf dan para tamu di Panorama Regency Hotel, Batam. Penulis telah melakukan analisis data. Penulis kemudian menemukan 109 data bahwa kesopanan positif terdiri dari 106 data, yaitu: strategi 1, 6 data $(5,40 \%)$, strategi 2, 3 data $(2,70 \%)$, strategi 3,5 data $(4,50 \%)$, strategi 4,10 data $(9,00 \%)$, strategi 5,23 data $(21,10 \%)$, strategi 6 , 5data $(4,50 \%)$, strategi 7,5 data $(4,50 \%)$, strategi 8,3 data $(2,70 \%)$, strategi 9,5 data $(4,50 \%)$, strategi 10,3 data $(2,70 \%)$, strategi 11, 5 data (4,50\%), strategi 12, 4 data (3,60\%), strategi 13, 7 data $(6,30 \%)$, strategi 14,1 data $(0,90 \%)$, dan strategi 15,7 data $(6,30 \%)$. Penelitian ini menyimpulkan bahwa strategi kesopanan positif didasarkan pada dialog antara staf hotel dan tamu yang telah menempati di Panorama Regency Hotel, Batam. Yang paling sering digunakan adalah strategi 5, 23 kali digunakan (21,10\%). Strategi ini bertujuan agar topik aman digunakan untuk memungkinkan pembicara menekankan persetujuan dengan pendengar. Dalam hal ini, pembicara melakukannya untuk menekankan persetujuannya dengan tamu. Oleh karena itu ini untuk memuaskan keinginan pendengar untuk menjadi 'benar' atau menguatkan pendapatnya. Oleh karena itu, sebagian besar staf hotel menggunakan perjanjian ketika mereka melayani pencarian. Hal ini dilakukan untuk membuat para tamu tidak mengeluh dan tinggal di rumah ketika mereka menginap di hotel.
\end{abstract}

Kata kunci: Kesopanan, Staf Hotel, Percakapan 


\section{Background of the Study}

A controlling communicate to interact for human being is by using a language, without language means no connection, no interaction, no communication, and no action. Now days language growth go along with scientist and technologies as we could found it in social life human being interaction, coding and symbols some register for science purpose.Wardhaugh (2002) in Risna (2009) said“" a language is a system of arbitrary verbal symbol which is used by the members of a speech community as a mean of communication to interact and express their ideas, feelings and thoughts." Therefore, all of those kind of language has ones aim to make communication between two or more peoples, group to some community, racial to others ethnic, and symbol to letter for register word purpose. According to Ningsih (2012) without language, people will face a lot of difficulties to communicate with others. As result there will be no interaction among people. As social creatures, human beings need their fellows to be able to live in the world. Therefore, it can be stated a human can not be separated from language since human needs language to communicate with others. In the communication of politeness is an important aspect of life for creating good communication between speakers and opponents said. Politeness strategy used to better appreciate others and ourselves. In everyday communication we cannot deliver a speech at any time with a courteous manner, and it will give the possibility could hurt the feelings of the opposite. According to Brown and Levinson (1987) politeness strategies used by speakers to avoid the threatened action against the other person's face. Face threatening acts are by Brown and Levinson (1987) called FTA (Face Threatening Act).

Therefore, in the terms ofcommunication, the writer willchoosea strategy to communicate politely. People use politeness strategies to get their conversation went well and running smoothly. Brownand Levinson (1987) states one recognizes what people do in averbal exchange (such as requesting, offering, criticizing, complaining, and suggesting) not so much by what they openly confess to suchfinesin detail the linguisticutterance.

In addition, the language use which released from mouth, gesture, body language is expression and reflection of our characteristic. According to Brown, (2001) that the language 
is a systematic tool meaning that is used to convey ideas or feelings by using that has meaning. By using the language a teacher can be hurting her studentand make the people's feeling is not balmy, but the language also can make students or the people balmy and happy.

Due to the thing above that most people use language as a tool of social interaction. According to Moskowitz (1978) therefore, children must have the opportunity to interact socially for language to develop adequately. Language has true central role in intellectual growth, social, and emotional. So this Language in life goes into society, so we need a policy which has implication of construction that study in education institute. It is based on the writer agree that language has positive and negative impact to the social life circumstance in every way. This chapter writer tried to expose language in services have various professional theorist and indicate to express some purpose in proper communicate. It can be identified in popular theorist pragmatic, sociolinguistic and psycholinguistic. Due to Leech (1983) in Watts (2003) pragmatic is concern to how language is used in communication. Pragmatic is to study the meaning in relation to speech situation. In others side he said that pragmatic deals with utterance meaning rather than sentence meaning. But, Levinson (1983) popular with his states that pragmatic is study of language use. It means one of language use is used to communicate with each others. Other than that, Yule (1996) explains that there are four definition of pragmatic, one of them is the study how more gets communicated that it said.

According to Wardhaugh (1989) we can show our feeling toward other. Solidarity power, distance, respect intimacy, and etc, and our awareness of social customs. Asian people mostly have own nature modals of politeness rather than others country in the world if we see from hospitality side. In the other hand, if we have a good modals above just makes little improve and polish our hospitality politeness with abilityservices in personal skill will have a better chance to succeed in their future career in hospitality services.

Every staff Panorama Regency Hotel has to understand impolite to the guest mostly occurred because services that we were not served in proper and the point is under-estimate of the guest expectation in guest psychology satisfaction, rises the good politeness refer to the guest should be able to felt every part of serve in our unit hotel are excellence, it is could see during their habit look enthusiasm, happy face act and their body gestures when served in the 
surrounding hotel from beginning enter the lobby hotel until during check out time from the hotel professional experience. Moreover, the staff hotel Panorama Regency Hotel can predict what should give the best ones communication services to the guest during in house in the hotel as line as with the Standard Operational Hotel studies. Such awareness is also shown through 'politeness' with which we use language. Politeness itself is socially prescribed. This does not mean that we must be polite. Therefore, the writer entitles this study on Positive politeness strategies used in conversation by hotel staff Housekeeping of Panorama Regency Hotel Batam.

\section{Identification of the Study}

This is based on the background of study above that has been described, the importance of the problems associated with this background. As for the problems that arise are as follows:

a. Lexical choice in serving the guest. Use of politeness strategies that appear of all staff in handling the guest.

b. This shows the background of the hospitality of the Hotel staff in serving the guests.

\section{Limitation of the Study}

There are many problems to be discussed in this study. Therefore the writer limits the study as follows:

a. This study will be limited in lexical choice used by Hotel Staff at Panorama Regency, Batam.

b. This study will be focused on the positive politeness of the universal politeness theory of Brown and Levinson (1987) used by Hotel Staff at Panorama Regency, Batam.

\section{Formulation of the Study}

This is based on the identification and limitation of the study above, the writer will suggest in this study, the writer would like to do the study about lexical choice and positive politeness strategy used by Hotel Staff at Panorama Regency, Batam.

a. What are the lexical choices used by Hotel Staff at Panorama Regency Batam?

b. What positive politeness strategies used by Hotel Staff at Panorama Regency Batam? 


\section{Objective of the Study}

The writer will explain about lexical choice and the politeness strategies used by Hotel Staff at Panorama Regency, Batam?

a. To describe how the lexical choice used by Hotel Staff at Panorama Regency, Batam?

b. To identify the positive politeness strategies used in teaching English?

\section{Significance of the Study}

The Significance of the Study can be obtained based on the data given in this study. Therefore, the writer expects that writers, readers and from the faculty of science teacher training has significance.

\section{Definition of the Key Terms}

In this study part, the writer will focuses on the theory of Politeness strategies are kinds of communication strategies that emphasizes on the polite words in action. (Brown and Levinson, 1987)

a) Pragmatics : According to Allwood (1993) explains that the term pragmatics originated from the Greek word Pragma which means action or activity handbook pragmatic; definition of "general pragmatics" will be further restricted to the study of linguistic communication in terms of conversational principles.

b) Study : Study is setting of the mind or thoughts upon a subject; hence, application of mind to books, arts, or science, or to any subject, for the purpose of acquiring knowledge. http://www.brainyquote.com/words/st/study224983.html

c) Positive politeness is redress directed to the addressee's positive face, his perennial desire that his wants (or actions/acquisitions/values resulting from them) should be thought of as desirable, (Brown and Levinson , 1987)

d) Strategies : Strategies are connotations of conscious deliberation that will imply a rational element covering:

Innovative plans of action, which may still be (but need not be) 
Routines - that is, previously constructed plans whose original rational origin is still preserved in their construction, despite their present automatic application as ready-made programmers.( (Brown and Levinson , 1987)

A strategy is one of the ways that need someone to create an action in the do activity to get and accomplish the goal. Definition of the others strategies is a word of military origin refers to a plan of action designed to achieve a particular goal. In military usage strategy is distinct from tactics, which are concerned with the conduct of an engagement, while strategy is concerned with how different engagements are linked, (en.wikipedia.org/wiki/Strategy).

\section{REVIEW OF RELATEDTHE LINGUISTICS}

This chapter consist of the basic theories on which the researcher fundamental analysis. The writer will use theory Pragmatically politeness during communicate with the hotel guest, and politeness strategies by using staff hotel used by Brown and Levinson and others related the study.

\section{Pragmatics}

In the oxford dictionary of Philosophy (2005) The part of theory of sign, or semiotic that concern the relationship between speakers and their signs. The study of principle of the governing appropriate conversational move is called general pragmatics, applied pragmatic treats of special kind of linguistics interaction such is interview and speech making. A pragmatic treatment of a feature of the use of a language would explain the feature in term of general principles governing appropriate utterance, rather than in term of semantics rules. For example, 'she had a baby and got married' and 'she got married and got baby' would be treat semantically if it were put down to the meaning of the term 'and', but pragmatically if were put down in general regularity that people relate events in the order in which they suppose them to have happened. According to Moris (1938), Cristal (1980), Hartmann and Stork (1972) explain that semantic and syntax is branch from semiotic that is about sign. There are three of semiotic, they are syntax, its branch of semiotic that study of related between formal and sign, second is semantics, branch of semiotic that examine the relationship with the sign with language users. Leech (1993) explain that treat semantics meaning as relationship involve 
two term' dyadic' as in 'what' does X?', while pragmatic treat meaning as a relationship involving the three term triadic 'as in' what do you mean by $\mathrm{X}$ ? So the pragmatic meaning can defined in conjunction with speakers or speakers of all languages. While the semantic meaning of the definition of the characteristic of the expression in a particular language, separate from the situation, speakers and his interlocutor. In other side, Parker (1986) explain that speaker reference included in the study of pragmatic. While the reference included in linguistics semantics. Fenegan (1992) also adds that the semantic sentence is not concerned with utterance meaning. Utterance are the subject of investigation of another branch linguistics called pragmatics.

\section{Politeness Theories}

According to the Brown and Levinson (1987) Theory Politeness strategy divide by four kinds, there are Bald on record, Positive politeness, Negative politeness and off the record. According to Lakoff (1973) claim that Grice maxim fall under the first pragmatic rule, since they mainly concentrate on the clarity of the conversation. She claimed that 'clarity' fall under the first rule of politeness: 'don't impose' and that the rules of conversation can thus be locked at as sub case of her first rule since the goal us the communicate the message in the shortest time possible with the last difficulty, without imposing on the addressee. She is implying that the rule of conversation are one type of politeness rule and since Grice consider his rule of conversation to be universal, Lakoff would be suggestion here, that type of politeness is universal applicable.

\section{a. Brown and Levinson Politeness}

According to brown and Levinson (1987) theory politeness strategy divided by four kinds, there are bald on record, positive politeness, negative politeness and off record. Brown and Levinson (1987) state the universal Politeness theory as an improvement of the idea from Grice's and Leech Maxim's. The universal Politeness theories is base on conversational practice of three ethnics communities, involving three unrelated and quite difference language. English, Tamil, and Tzeltal. Each of these languages demonstrate similarities in the way its respective speaker apply strategies to show politeness in rational communication. Brown and Levinson refer a Model Person (MP). An MP consist of a fluent speaker of a natural language 
who is indowed with the properties of rationality, that is to say, the ability to reason from ends to mean that means that will satisfy those ends, and 'face'. The key concept of theories Brown and Levinson is idea of the 'face'. Brown and Levinson interpreted of the term derive from Goffman (1967) and from the English folk term 'losing face' and 'saving face'.

\subsection{Positive Politeness}

According to Brown and Levinson, (1987) state that positive politeness is redress directed to addressee's positive face by approving or including the addressee as a friend or a member of a group. In other words, positive politeness is a politeness strategy used to satisfy the positive face of the hearer. It is solidarity oriented. Positive politeness is used by the speaker to give an impression that he/she wants hearer's wants, or in other words, speaker wants the hearer's face to be satisfied.

Positive politeness also used by strangers in the interaction to get closer to the hearer. The positive face is to show rationally that everybody wants their face preserved, and they wants to be appreciated. Thus the hearer needs to respect or face want from the speaker. Positive politeness is used as a kind of social acceleration.

Brown and Levinson (1987) explain that there are fifteen (15) strategies of positive politeness, such as:

(i) Strategy 1 : Notice, attend to H (his interest, wants, needs, goods)

In general, this output suggest that $\mathrm{S}$ should take notice of aspects of H's condition (noticeable changes, remarkable possessions, anything which look as though $\mathrm{H}$ would want $\mathrm{S}$ to notice and approve of it). Example used as FTA include in English: a compliment, an offer, or a request. Example:

a. Goodness, you cut your hair! (...)By the way, I came to borrow some flour.

b. You must be hungry; it's a long time since breakfast. How about some a lunch?

c. What a beautiful vase this is! Where did it come from?

(ii) Strategy 2 : Exaggerate (interest, approval, sympathy with $\mathrm{H}$ )

This is often done with exaggerated intention, stress, and other exaggerated or emphatic words/particles (e.g. for sure. Really, exactly, absolutely). For examples: 
a. What a fantastic garden you have!

c. That's a nice hair cut you got; where did you get it?

(iii) Strategy 3 : Intensity Interest to $\mathrm{H}$

Another way for $\mathrm{S}$ to communicate to $\mathrm{H}$ that he shares some of his wants is intensity the interest of his own $(\mathrm{S}, \mathrm{s})$ contributions to the conversation, by 'making a good story'. This may be done by using the 'vivid present' direct speech, taq question, or expressions such as these examples from Rozina (2004) for example ; this a common feature of positive-politeness conversations, as it pulls $\mathrm{H}$ right into the middle of the events being discussed, metaphorically at any rate, to increase H's interest and to draw him into the conversation.

For example : I come down the stairs, and what do you think I see? - a huge mess all over the place, the phone's off the book and clothes are scattered all over...

(iv) Strategy 4: Use in-group identity markers.

This strategy includes in-group usages of address forms, of language or dialect or slang, and of ellipsis. Other address forms used to convey such in group membership include terms of address like: Mac, mate, buddy, pal, honey, dear, dukie, luv, babe, mom, blonde, brother, sister, cutie, sweetheart, and guys, fell as. Such forms may be used to soften FTAs:

a. Here mate, I was keeping that seat for a friend of mine.

b. Help me with this bag here; will you pal/lup/son?

Using such in-group kinds of address forms with imperatives,

a. Come here, honey/buddy/mate.

b. Bring me your dirty clothes to wash, honey/darling/Johnny.

(v) Strategy 5 : Seek agreement (to find and try to approval by the opponent said)

For this strategy there are two ways to seek agreement, such as safe topics and repetition. Safe topics are used when speaker stresses his agreement with hearer and therefore to satisfy hearer's desire to be right. Agreement may also be stressed by repeating part or some utterances in conversation and by using particles that function 
to indicate emphatic agreement such as: yes, uh huh, really, etc. So, in his strategies the speaker repeat some utterances of opponent said that he/she agree and follow any information that is spoken by the opponents said, as example in this dialogue:

A: John went to London this weekend!

B: To London!

A: I had a flat tyre on the way home.

B: Oh God, a flat tyre!

(vi) Strategy $6:$ Avoid disagreement

This strategy sees S using the 'Token' agreement (Yes, but, then and so) to convey disagreement. $\mathrm{H}$ in reciprocate shows that he or she agree but actually he disagree with $\mathrm{S}$. The desire to agree or appear to agree with $\mathrm{H}$ leads also to mechanisms for pretending to agree, instances of 'token' agreement. Sack (1973) has collected numerous examples in English of the remarkable degree which speaker may go I twisting their utterances so as to appear to agree or to hide disagreement - to respect to a preceding utterances with 'Yes' but... in effect, rather than a blatant 'No' In the use of this strategies, the speaker try to avoid his disapproval with the utterances of opponent speech. Hence, Rozina (2004) states that H might say "Yes, but,...then and so" to indicate a real or false conclusion to prior agreement for requests and offers, white lies to refuse a requests, and hedges (e.g. sort of, kind of, like, in a way) for complaints, criticism or suggestions.

Example in conversation:

A: That's where you live, Florida?

B: That's where I was born.

A: What is she, small?

B: Yes, yes, she's small, smallish, um, not really small but certainly not very big.

A: You hate your Mom and Dad?

B: Oh, sometimes. 
(vii) Strategy 7 : Presuppose / raise / assert common ground

In this strategy small talk used by Speaker.The value of S's spending time and effort on being with $\mathrm{H}$, as a mark of friendship or interest in him, gives rise to the strategy of redressing an FTA by talking for a while about unrelated topics. Scan thereby stress his general interest in $\mathrm{H}$, and indicate that he hasn't come to see $\mathrm{H}$ simply to do the FTA (e.g. a request), even though his intent to do it may be made obvious by his having brought a gift. This strategy is intended to soften request for a favor. The strategy used includes:

a. Point-of-view operations: In all languages sentence may encode point of view or deixis.

b. Personal-centre switch: $\mathrm{S}$ speaks to $\mathrm{H}$ as if $\mathrm{H}$ is $\mathrm{S}$. An example is the use of tag question with falling intonation in some local dialect of British English.

Example: I had a really hard time learning to drive, didn't I?

a. Time switch (vivid present: past tense switch to present)

Example: John says he really loves roses.

d. Place switch (here and this than there and that),

Example: This/that was a lovely party.

a. Avoidance of adjustment of reports to H's point of view. The direct form of quoted speech in English is associated with stereo type of the working class. Whereas, in Tzetal and Tamil, direct quoted speech is very generally used as a positive politeness.

f. Presuppose knowledge of H's wants to attitude. Negative questions which presume yes as an answer are widely used as way to indicate that $\mathrm{S}$ knows H's want, taste, habits, etc. This is to redress the FTAs, for example in offer or requests.

g. Presuppose H's values are the same as S's values. The use of scale predicate such as 'tall' assumes that $\mathrm{S}$ and $\mathrm{H}$ share the criteria for placing people (or things) on this scale. 
h. Presuppose familiarity in speaker-hearer relationship. Familiarity will increase through the use of such familiar address forms as honey and darling.

i. Presuppose hearer's knowledge. This refers to the use of terms that presuppose H's knowledge of in-group codes (in-group language, jargon, dialect, local terminology) and pronouns.

(viii) Strategy 8 : Joke (make a joke)

Since jokes are based on mutual shared background knowledge and values, jokes may be used to stress that shared background or those shared values. Joking is a basic positive-politeness technique, for putting $\mathrm{H}$ 'at ease' for example in response to a faux pas of H's, S may joke or a joke may minimize an FTA of requesting, as:

a. OK if I tackle those cookies now?

b. How about lending me this old heap of junk?

(ix) Strategy 9: Assert or presuppose Speaker's knowledge of and concern for Hearer'swants.

This strategy use to indicate that $\mathrm{S}$ and $\mathrm{H}$ to co-operators. Hence $\mathrm{S}$ pushes $\mathrm{H}$ to cooperate with speaker S is to assert or imply knowledge of H's wants and willingness above may sometimes function in this way, This include doing the FTA of offers and requests as many utterances like the following:

a. Look, I know you want the car back by 5.0, so shouldn't I go to town now? (request)

b. I know you can't bear parties, this one will really be good - do come! (Request/offer)

c. I know you love roses but the florist didn't have any more, so I brought you geraniums instead. (offer + apology)

(x) Strategy $10:$ Offer, promise

In order to redress the potential threat of some FTAs. Hence, S may choose to stress his cooperation with $\mathrm{H}$ in another way. He may, that is, claim that (within a certain sphere of relevance) whatever $\mathrm{H}$ wants, $\mathrm{S}$ wants foe him and will help to obtain. 
Offers and promises are the natural outcome of choosing this strategy; even if they are false. Usually this strategy often used in interaction. Example: I'll drop by sometime next week.

(xi) Strategy $11:$ Be optimistic

This strategy assumes that $\mathrm{H}$ wants $\mathrm{S}$ 's wants for s (or for $\mathrm{S}$ and $\mathrm{H}$ ) and will help $\mathrm{S}$ to obtain them. To simply, $\mathrm{H}$ makes tacit claim that $\mathrm{H}$ will cooperate with $\mathrm{S}$ and it will be done with mutual shared interests. This is done with the use of a little, a bit, for a second or token tag (e.g. OK? do you...won't you?) for requests.

Example: Wait a minute; you haven't brushed your hair! (as a husband goes out the door).

(xii) Strategy 12 : Include both $\mathrm{S}$ and $\mathrm{h}$ in the activity.

This strategy use an inclusive 'we' form, when S really means 'you' or 'me', he can call upon the cooperative assumptions and thereby redress FTAs. Nothing that let's in English is an inclusive 'we' form, common examples are:

a. Let's have a cookie, then. (i.e. me)

b. Let's get on without dinner, eh? (i.e. you)

c. Give us a break. (i.e. me)

(xiii) Strategy 13 : Give ( or ask for ) reasons

Another aspect of including $\mathrm{H}$ in the activity is for $\mathrm{S}$ to give reasons as to why he wants what he wants. By including $\mathrm{H}$ thus in his practical reasoning, and assuming reflexivity (H wants S's wants), $\mathrm{H}$ is thereby led to see the reasonableness of S's FTA (or so S hopes). In other words, giving reasons is a way of implying 'I can help you' or 'you can help me', and assuming cooperation, a way of showing what help is needed. For examples:
a. Why not lend me your cottage for the weekend?
b. Why don't we go to the seashore?
c. Why don't I help you with that suitcase? 
(xiv) Strategy 14 : Assume or assert reciprocity

The existence of cooperation between $\mathrm{S}$ and $\mathrm{H}$ may also be claimed or urged by giving evidence of reciprocal rights or obligations obtaining between $\mathrm{S}$ and $\mathrm{H}$. Thus $\mathrm{S}$ may say, in effect, 'I'll do X for you if you do $\mathrm{Y}$ for 'me', or 'I did X for you last week, so you do Y for me this week' (or vice versa). By pointing to the re-cipropocal right (or habit) of doing FTAs to each other, S may soften his FTA by negating the debt aspect and /or the face-threatening aspect of speech acts such as criticisms and complaints.

Fulfill H's want for some X. Our last positive - politeness strategy involves S decide $g$ to redress H's face directly by fulfilling some of H's wants, thereby indicating that he $(\mathrm{S})$ wants for $\mathrm{H}$, in some particular respect.

Example: I'll buy you a mansion if you marry me.

(xv) Strategy 15 : give gifts to H (goods, sympathy, understanding, cooperation)

Finally, S may satisfy H's positive - face want (that $\mathrm{S}$ wants, to some degree) by actually satisfying some of H's wants. Hence we have the classic positive politeness action of gift giving, not only tangible gifts (which demonstrate that $S$ knows some of H's wants and wants them to be fulfilled), but human-relations wants such as those illustrated in many of the outputs considered above-the wants to be liked, admired, cared about, understood, listened to, and so on. Examples:

a. I understand how you feel.

b. I am sorry to hear that.

\subsection{Hospitality of the Hotel Staff}

Procedure purpose of Housekeeping department as a main operation in the hotel leads important communication in internal department. Keep maintain with other team in management as supporting others department surrounding hotel, until keep the guest comfortable and excellence services as well as. To implemented professional services hotels management state the policy in operating procedure as following; 


\section{Departmental communication}

Communication in operational must continue at whole time, that means up dating information between staff housekeeping is priority to make sure avoid complaint happened. The good communication in housekeeping department consist of following;

a) The communication between the Housekeeping Management Team and the Housekeeping staff shall be continuous in order to ensure that the required tasks have been completely and precisely understood and to check the quality of the performance.

b) Every specific required task shall be visually displayed, i.e., flow chart, tangible example, etc., in order to avoid any language problem.

c) Actual demonstrations shall be systematically performed in order to avoid complicated explanations that may lead to misunderstanding.

d) All staff questions shall be answered after having carefully listened to them. Reformulation and feedback are to become a reflex action.

e) Repetition shall be stimulated and the result checked for accuracy in understanding.

f) Permanent availability of the Housekeeping Management Team is mandatory.

\section{Management by objective}

To ensure the management goal in services as well as staff understand management obtained purpose of Standard Operational Procedure by used as guide line in operate As following;

a) All Housekeeping employees shall be able to set and achieve appropriate goals for their personal growth and development. The Housekeeping Management Team shall ensure that all Housekeeping staff are well trained as per established hotel standards and as described by its procedures. 
b) The Housekeeping Management Team shall hold meetings on a regular basis (the frequency to be established in co-operation with the Human Resources Division) to provide staff with the latest information regarding the hotel overall and departmental current and upcoming operations.

c) The Housekeeping Management Team shall hold meetings on a regular basis (the frequency to be established in co-operation with the Human Resources Division) to discuss all departmental problems, before they occur and/or worsen, and to improve departmental performance.

d) The Housekeeping Management Team is responsible for the consistency of the standard of performance of the Housekeeping Department and must consequently conduct adequate training programs at appropriate times.

e) The Housekeeping Management Team shall strive to increase the number of repeat guests

f) Due to good service. The Housekeeping Management Team must stress the importance of the spirit of cost-saving.

\section{Problem solving spirit}

a) All Floor Supervisors shall understand the nature of the working relationship and always try to improve the work quality of the staff by solving problems quickly and efficiently.

b) Consequently, the staff shall carefully but discreetly be observed in their working environment, especially their behavior as they interact with others, both guests and staff.

c) The staff shall be asked if they require any assistance regarding their problems, both professional and personal, without delaying/disturbing their tasks.

d) Sincerity, kindness and co-operation are always to be displayed and the staff are encouraged to discuss problems. 
e) This behavior is aimed both at providing the staff with self-confidence and well-being and increasing guest satisfaction, as staff seeing others solve their own problems will be motivated to solve the guests' problems.

\section{Quality Standard Communication Set-up}

Character of work established from how to build good relationship between the staff in working communication internal or external. There is not personal character communication automatic comes in staff itself unless state standard communication set up. There are as following;

\section{a. Notice board}

1) The notice board will be regularly up date in order to ensure real time communication and shall display the following information :

2) The per floor/per pantry availability of items such as cots, rollaway beds, etc.

3) All guests' special requirements with the room number and the guest's status (all maintenance operations are to be directly forwarded and performed).

4) The cleaning sessions to be performed on the current day, i.e., floor carpet cleaning, and any special needs, i.e., room sofa cleaning, etc.

\section{b. General log book \& Maintenance log book}

1) All guests' requests for extra amenities and complaints shall be recorded in the log book on a shift basis.

2) The log book shall be divided into different column headings displaying the following information :

1. Date of issue / Date of request

2. Room number

3. Item reference / Technical service to be performed

4. Date of return not to be after the guest's checkout date 
3) When a guest calls and wishes to borrow any item, the request shall be logged in and all details accurately recorded in order to respond to the guest's demand as satisfactorily as possible. Any technical problems shall be described as well.

4) The Room Attendant shall follow up through the Floor Supervisor in order for the issued items to be returned on time and/or the technical problem to be solved. The Room Attendant shall register the date of return with the Floor Supervisor's signature and/or acknowledge that maintenance action has been completed.

\section{c. General information}

Each Housekeeping staff member must accurately and completely know the hotel layout :

1. All guest floors and their respective room display

2. The reception area

3. The recreational areas

Consequently, each Housekeeping staff member shall be able to provide the guest with the following information :

1. The location of all the F \& B outlets and the function rooms

2. The capacity and the concept, i.e., food style, price range, entertainment, etc.

3. The operating hours and the internal phone extension for reservation Before communicating any information to the guests, the Housekeeping staff member shall first understand the guest's request by repeating it, and also understand the provided answer thanks to good product knowledge.

The Housekeeping staff member shall connect the guest to the appropriate Department for further information if necessary. 


\section{d. Telephone answering}

1) Every call must be answered politely and clearly within the first 3 (three) rings. The guest shall feel that the person to whom she/he is speaking will take care of her/his needs and take the necessary action as required.

2) The Housekeeping staff member must answer any telephone call within the first 3 (three) rings by saying : "Housekeeping, how may I help you ?" and by adding the guest's family name well pronounced, if displayed alphanumerically.

3) Any Housekeeping staff member must address all callers in a professional and polite manner.

4) All incoming calls that request any action and follow-up shall be recorded in the related log book (General or Maintenance) with the following details:

1. Time

2. Subject

3. Action taken

\subsection{Appropriate Problem-dealing behavior Guest satisfaction.}

A hotel guest is the reason we are working in the hotel. Consequently, the two following behaviors shall always be permanently and systematically applied :

1. Any guest request/complaint shall be received with respect by carefully listening to what the guest says, and by acknowledging the subject by repeating it once the guest has finished speaking

2. Courtesy and politeness are mandatory when dealing with a guest, whatever the subject

\section{1) Complaint}

a. The Room Attendant shall thank the guest for bringing the problem to her/his attention.

b. If the Room Attendant is not sure about any solution, she/he shall reassure the guest by handing the complaint over to the Floor Supervisor concerned 
c. Even where the complaint is being handled by the relevant person, the Room Attendant shall remain available until a satisfactory solution is found.

\section{2) Request}

a. The Room Attendant shall politely reply to the guest by giving the correct information and acting accordingly after having carefully listened to the guest's request.

b. If the Room Attendant is not $100 \%$ sure about the way to act, the Room Attendant shall seek for the most suitable person to help her/him.

c. The Room Attendant shall follow up the request with the relevant person.

\section{3) General dealing.}

a. The Room Attendant shall be courteous

b. The Room Attendant shall greet the guest by her/his correctly pronounced family name whenever possible

c. If the Room Attendant does not know the answer to a question, she/he shall immediately find someone who does

\subsection{Problem dealing procedure}

1) The objective is to take immediate action and advise the superior concerned.

2)Consequently, when receiving any guest complaint / request, the

Followingdetails shall be obtained

1. Guest's name

2. Room number

3. Complaint / request description

3) The guest shall be assured that the complaint / request will be attended to immediately and reported to the superior concerned. 
4) The complaint / request is to be accordingly recorded in the General log book, or the Maintenance log book if any technical problem has occurred, and which shall be handed.

5) A feedback / verification call shall be systematically made as trained.

\section{RESEARCH METHODOLOGY}

In this chapter, the writer will describe the positive politeness strategies employed by Panorama Hotel Staff Batam. This consists of Research design, Source of the Research Data, Procedures of the Data Collection, and procedures of the Data Analysis. Those are as follows:

\section{Research Design}

In this research, the use of method in a research is important and necessary, because it will be able to help a researcher to get the data and then, the writer can analyzes this study based on the data. According to Cresswell (2003), there are three approaches to research, namely A quantitative approach, qualitative approach, and mixed methods approach.

a. The quantitative approach is one in which the investigator primarily uses post positivist claims for developing knowledge (i.e., cause and effect thinking, reduction to specific variables and hypotheses and questions), employs strategies of inquiry such as experiments that yield statistical data.

b. The qualitative approach is one in which in the inquirer often makes knowledge claims based primarily on constructivist perspectives (i.e., the multiple meanings of individual experiences, meaning socially and historically constructed with an internet of developing the theory or pattern).

e. The mixed methods approach is one in which the researcher tends to base knowledge claims on pragmatic grounds (i.e., consequence-oriented, problem centered, and pluralistic.

In this study, the writer use descriptive qualitative approach in analyzing of the data in which the writer will collect from the hotel staff are containing the positive politeness strategies based on Brown and Levinson's theory (1987).

So, in this study use the Brown and Levinson's politeness theory to describe positive politeness strategies by using descriptive qualitative method in analyzing of study on positive 
politeness strategies for services in Panorama Regency Hotel, and how to analyzing the data obtained.

\section{Source of the Research Data}

The writer focuses on this study in services staff Housekeeping to in house guest hotel Panorama Regency Batam. A data source can be in the form of telephone courtesy services book, Person in charge in services, or making the dialogue. According to Suharsimi (2006) explains in general that the data source can be grouped into be three types as follows (1) people (2) paper and (3) place. In addition, Creswell (2003) explains one of characteristic of qualitative research takes place in the natural setting. This enables the researcher to develop a level of detail about the individual or place and to be highly involved in actual experiences of the participants. Therefore, qualitative research uses multiple methods that are interactive and humanistic. The data collection are growing, and they increasingly involve active participation by participants and sensitivity to the participants in the study. In addition, the actual methods of data collection, traditionally based on open-ended observations, interviews, and documents, now include a vast array of materials, such as sounds, e-mails, scrapbooks and other emerging forms. The data collected involve text (or word) data and images (or picture) data.

In this case, the data used by the writer will obtain the data based on the hotel staff when they are handling the guests. Therefore, the types of the data collection is two types. Those are:

\section{A. Primary Data}

Primary data is the data that the writer will use the conversation between hotel staff and the guest of Panorama Regency Hotel - Batam.

\section{B. Secondary Data}

The writer will read from some pragmatic books, article, journals, download, downloaded from internet.

\section{Procedures of the Data Collection}

In collecting the Data, the data collecting technique is very important thing to be used, therefore, it is a technique to get and to collect the data. It can be done by making a dialogue, policy of Standard Operating Procedure hotel, or excellence services training materials. While, 
Creswell (2003) the data collection steps include setting the boundaries for the study, collecting information through unstructured (or semi-structured) observation and interviews, documents, and visual materials, as well as establishing the protocol for recording information. The writer will have steps as below:

a. Observation of the objects (staff)

b. Making notes of the dialogue.

c. Preparing of the Time of data Collection

\section{Procedures of the Data Analysis}

The writer uses the theory of politeness strategies based on Brown and Levinson (1987). And then the writer analyzes the positive politeness strategies used by hotel staff. The steps of analyzing is as follows

a. Firstly, the writer will analyze the notes first. The writer explains the data based on the lexical data, whether they are according to words.

b. Secondly, the writer then analyzes positive politeness based on the politeness theory of Brown and Levinson (1987)

c. Finally, the writer makes a conclusion and suggestion based on the whole previous chapters.

\section{FINDING AND DISCUSSION}

In this chapter, It deals with the data finding and discussion based on Brown and Levinson's Politeness theory (1987). Therefore, the writer will discuss the answer to the formulation of the study. After analyzing the data, the writer divides this chapter into two parts of analysis. The first part is data findings. The second is discussion of positive politeness strategies used by Hotel Staff at Panorama Regency Batam. It is for more detailed explained as following parts;

\section{Data Findings}

This study is going to describe of the analysis of the data by using Brown and Levinson's theory of positive politeness strategies. The strategies used by universal politeness. The data are obtained from the dialogue between hotel staff of Panorama Regency Hotel with guest in service of the hotel. 
The data of this study use the notes and recorder when the hotel staff handling the guests at the Panorama Regency Hotel. From the data that have been analyzed, the writer found out of positive politeness as suggested by Brown and Levinson (1987). Those are as below:

The data finding there were 109 times occurred based on the conversation between the staff and the quests at the Panorama Regency Hotel, Batam. The writer has carried of the data analysis. The then writer found 109 data that positive politeness consist of 106 data, they are: strategy 1, 6 data $(5,54 \%)$, strategy 2, 3 data (2,53\%), strategy 3, 5 data(4,58\% ), strategy 4, 10 data $(9,17 \%)$, strategy 5, 23 data(20,10\%), strategy 6, 5data(4,58\%), strategy 7, 5 data $(4,58 \%)$, strategy 8,3 data $(2,53 \%)$, strategy 9,5 data $(4,58 \%)$, strategy 10, 3 data $(2,53 \%)$, strategy 11,5 data $(4,58 \%)$, strategy 12,4 data $(3,66 \%)$, strategy 13,7 data $(6,42 \%)$, strategy 14,1 data $(0,91 \%)$, and strategy 15,7 data $(6,42 \%)$.

\section{Discussion}

As stated by Brown and Levinson, (1987:70) state that positive politeness is redress directed to addressee's positive face by approving or including the addressee as a friend or a member of a group. In other words, positive politeness is a politeness strategy used to satisfy the positive face of the hearer. It is solidarity oriented. Positive politeness is used by the speaker to give an impression that he/she wants hearer's wants, or in other words, speaker wants the hearer's face to be satisfied. Therefore, this part will discuss the strategies of the Hotel Staff at Panorama Regency, Batam. This will be based the fifteen strategies used in service

\section{CONCULSSION AND SUGGESTION}

In this study, chapter consists of two main parts. The first is conclusion. The second is suggestion. Therefore, those will be more detailed as follows;

\section{Conculssion}

In this chapter, the writer will conclude this study based on the conversation between the staff with the guests. This study is analyzed by Brown and Levinson's Politeness theory (1987). Therefore, the writer will discuss the answer to the research question or formulation of the study. 
The data finding there were 109 times occurred based on the conversation between the staff and the quests at the Panorama Regency Hotel, Batam. The writer has carried of the data analysis. The then writer found 109 data that positive politeness consist of 106 data, they are: strategy 1, 6 data $(5,54 \%)$, strategy 2, 3 data (2,53\%), strategy 3, 5 data(4,58\% ), strategy 4, 10 data $(9,17 \%)$, strategy 5, 23 data(20,10\%), strategy 6, 5data(4,58\%), strategy 7, 5 data $(4,58 \%)$, strategy 8,3 data $(2,53 \%)$, strategy 9,5 data $(4,58 \%)$, strategy 10, 3 data $(2,53 \%)$, strategy 11,5 data $(4,58 \%)$, strategy 12,4 data $(3,66 \%)$, strategy 13,7 data $(6,42 \%)$, strategy 14,1 data $(0,91 \%)$, and strategy 15,7 data $(6,42 \%)$.

The result of the discussion of the positive politeness strategies based on the dialogue between the hotel staff and the guest who has occupied at Panorama Regency Hotel, Batam. The most frequently used is strategy 5, 23 times used (20,72\%). This strategy is aimed to safe topics are used to allow speaker to stress agreement with hearer. In this case, the speakers do it to stress his agreement with hearer and therefore to satisfy hearer's desire to be 'right' or corroborated in his opinion. Therefore, mostly hotel staff used agreement when they serve the quests. This is done to make the guests do not complain and stay at home when they stay at the hotel.

\section{Suggestion}

In carrying this study, the writer has realized that this study is not so perfect. Therefore, the writer suggest as follows:

a. The conversation between the hotel staff and the guest can be studied from sociolinguistic in term of stylistics.

b. The conversation between the hotel staff and the guest can be studied from linguistic features.

c. The conversation between the hotel staff and the guest is also used to improve students motivation of learning English for special purpose.

\section{BIBLIOGRAPHY}

Arikunto, Suharsisni. 2006. Prosedur Penelitian: Suatu Pendekatan Praktik. Jakarta: PT RinekaCipta. 
Biber, Douglas and Finegan, Edward. 1994. Sociolinguistics Perspective on Register. New York: Oxford University Press.

Creswhell, John W. 2003. Research design: Qualitative, quantitative, and mixed methods. United States of America

Daniek, Novem. 2008. Register study used in Caving Devision. Surakarta: Thesis UMS: Unpublished.

Gorrel, A. 1967. Words and morphemes. London:Longman Group Ltd.

Gioyoto, 2006. Grammar II. Surakarta: IAIN Surakarta Press

Holmes, Janet. 2002. An Introduction to Sociolinguistics. Endiburg: Person Education Limitted.

Hymes, Dell. 1973. Foundations in Sociolinguistics: An Ethnographic Approach. Philadelphia: University of Pensylvania Press.

Halliday, MAK and Hasan, Ruqoiyah. 1978. Language Context and Text. Melbourne, Victoria Deakin University.

Ichsanto Fauzi. 2000. A Descriptive analysis of register used by prostitutes in Surakarta.

John Lyons. 1997. Semantics. Volume I. Cambridge University Press. Cambridge. Great Britain.

Jendra, Made Iwan Indrawan, 2010.Sociolinguistics: The study of Societies. Yogyakarta: Graha Ilmu.

Leech, Geoffrey. 2003. Semantic (Translator: Paina Partana). Yogyakarta: Pustaka Pelajar

Moeloeng Lexy. J. 1989. Metodologi Penilitian Kuantitatif. Jakarta: Depdikbud.

Ndraha, Taziliduhu. 1981. Research: Teori, Methodologi, Administrasi. Jakarta: T. Bina Aksara.

Pateda, Mansoer. 2002. Semantic Leksikal. Edisi Kedua. Bandung: Rinekacipta

Risna. 2009. A study on register used by Orayza FM Radio Community at the University of Brawijaya. Malang: Universitas of Brawijaya. 